\title{
The impact of maternal lipid levels of non-diabetic pregnant women on fetal weight
}

\author{
İbrahim Uyar', Alev Timur², İbrahim Gülhan', Cenk Gezer', \\ Ferhat Çetin', Mehmet Özeren ${ }^{1}$ \\ ${ }^{1}$ Clinics of Obstetrics and Gynecology, Tepecik Training and Research Hospital, Izmir, Turkey \\ ${ }^{2}$ Clinics of Obstetrics and Gynecology, Private Sada Hospital, Izmir, Turkey
}

\begin{abstract}
Objective: It is aimed to evaluate the impacts of maternal lipid levels of non-diabetic pregnant women on fetal birth weight.

Methods: A total of 120 patients who admitted to our maternity ward of our hospital and had $50 \mathrm{~g}$ glucose screening test results lower than $135 \mathrm{mg} / \mathrm{dL}$ were included to our study and the levels of total cholesterol (TC), triglyceride (TG), high density lipoprotein (HDL) and low density lipoprotein (LDL) were measured in their fasting blood between 25 and 35 weeks of gestation. The patients were separated into two groups by taking $250 \mathrm{mg} / \mathrm{dL}$ of TG value as threshold (Group I: TG<250, Group II: $\geq 250$ ). Both groups were compared in terms of age, fetal birth weight, glucose screening, and delivery weeks.

Results: It was found that the mean age of patients was $27.65 \pm 5.40$, mean BMI was $28.29 \pm 4.24$, and mean lipid measurement week was $28.29 \pm 4.24$. The mean delivery week and birth weight were $38.53 \pm 2.11$ and $3295.75 \pm 564.58 \mathrm{~g}$, respectively. Mean glucose screening, and the values of TC, TG, HDL and LDL were found as $99.32 \pm 19.49 \mathrm{mg} / \mathrm{dL}$, $243.01 \pm 44.24 \mathrm{mg} / \mathrm{dL}, 255.28 \pm 90.27 \mathrm{mg} / \mathrm{dL}, 68.44 \pm 18.52 \mathrm{mg} / \mathrm{dL}$ and $123.21 \pm 37.11 \mathrm{mg} / \mathrm{dL}$, respectively. The mean ages of both groups (Group I and Group II) were 27.8 \pm 5.3 and 27.5 \pm 5.4 , the mean fetal birth weights were $3343.5 \pm 451.1$ and $3241.0 \pm 671.4$, the mean glucose screening values were $100.1 \pm 19.2 \mathrm{mg} / \mathrm{dL}$ and $98.3 \pm 19.8 \mathrm{mg} / \mathrm{dL}$, and the mean delivery weeks were $38.4 \pm 1.6$ and $38.6 \pm 2.5$, respectively. There was statistically no significant difference between both groups in terms of age, fetal birth weight, glucose screening values and delivery weeks. There was also no correlation between TG levels and fetal weight.

Conclusion: According to our study, no relationship was found between fetal birth weights and lipid parameters of non-diabetic pregnant women.
\end{abstract}

Keywords: Fetal weight, lipid levels, pregnancy.

\section{Özet: Diyabetik olmayan gebelerde maternal lipid seviyelerinin fetal ağırlık üzerine etkisi}

Amaç: Diyabetik olmayan gebelerde maternal lipid seviyelerinin fetal doğum ağırlığı üzerine olan etkilerinin değerlendirilmesi.

Yöntem: Çalışmaya hastanemiz gebe polikliniğine başvuran ve 50 g glukoz tarama testi sonuçları $135 \mathrm{mg} / \mathrm{dL}$ altında olan 120 hasta dâhil edilerek, 25-35. haftalar arasında açlık kanında total kolesterol (TK), trigliserit (TG), yüksek dansiteli lipoprotein (HDL), düşük dansiteli lipoprotein (LDL) düzeyleri ölçüldü. Hastalar TG değerleri $250 \mathrm{mg} / \mathrm{dL}$ eşik değer alınarak iki gruba ayrıldı (Grup I: TG<250, Grup II: $\geq 250$ ). Her iki grup yaş, fetal doğum ağırlı̆̆ı, glukoz tarama ve doğum haftaları açısından karşılaştırıldi.

Bulgular: Hastaların yaş ortalaması $27.65 \pm 5.40$, ortalama VKİ $28.29 \pm 4.24$ ve ortalama lipid ölçüm haftası $32.18 \pm 3.03$ bulundu. Ortalama doğum haftası ve doğum ağırlığı sırasıyla $38.53 \pm 2.11$ ve $3295.75 \pm 564.58$ gram idi. Ortalama glukoz tarama, TK, TG, HDL ve LDL değerleri sirasıyla $99.32 \pm 19.49 \mathrm{mg} / \mathrm{dL}, 243.01 \pm 44.24$ $\mathrm{mg} / \mathrm{dL}, 255.28 \pm 90.27 \mathrm{mg} / \mathrm{dL}, 68.44 \pm 18.52 \mathrm{mg} / \mathrm{dL}$ ve $123.21 \pm 37.11$ $\mathrm{mg} / \mathrm{dL}$ saptand. Her iki grubun (Grup I ve Grup II) yaş ortalaması sirasıyla $27.8 \pm 5.3$ ve $27.5 \pm 5.4$, ortalama fetal doğum ağırlığ $3343.5 \pm$ 451.1 ve $3241.0 \pm 671.4$, ortalama glukoz tarama değerleri $100.1 \pm 19.2$ $\mathrm{mg} / \mathrm{dL}$ ve $98.3 \pm 19.8 \mathrm{mg} / \mathrm{dL}$, ortalama doğum haftas $38.4 \pm 1.6$ ve $38.6 \pm 2.5$ idi. Her iki grup arasında yaş, fetal doğum ağırlığı, glukoz tarama ve doğum haftaları açısından istatistiksel olarak anlamlı fark saptanmadı. Ayrıca TG düzeyleri ile fetal ağırlık arasında korelasyon saptanmadi.

Sonuç: Çalışmamıza göre diyabetik olmayan gebelerde lipid parametreleri ile fetal doğum ağırlıkları arasında bir ilişki bulunmamıştir.

Anahtar sözcükler: Gebelik, lipit düzeyleri, fetal ağırlık.
Correspondence: Dr. İbrahim Uyar. Tepecik Eğitim ve Araştırma Hastanesi Kadın Doğum Kliniği, İzmir, Turkey.

e-mail: iuyar03@yahoo.com

Received: November 9, 2013; Accepted: January 27, 2014
Available online at: www.perinataljournal.com/20140222002 doi: $10.2399 / \mathrm{prn} .14 .0222002$ QR (Quick Response) Code: 


\section{Introduction}

Many changes occur during pregnancy in physiological and biochemical aspects. Prominent changes are also observed in maternal lipid metabolism. ${ }^{[1,2]}$ It is considered that maternal lipid levels increase until second trimester and even third trimester and this increase is very significant for fetal development and lactation. ${ }^{[3]}$

Hypertriglyceridemia is a characteristic feature of pregnancy. ${ }^{[4]}$ These changes are in favor of fetus and necessary for fetal development. Every substance or hormone that can pass beyond the placenta may affect fetus. The most typical example is the macrosomia observed in the fetuses of pregestational or gestational diabetic mothers. As explained by Pederson for the first time, macrosomia appears when hyperglycemia of mother causes hyperinsulinemia, and consequently causing hyperglycemia and hyperinsulinemia in fetus. ${ }^{[5]}$ In various studies, it has been reported that there is a relationship between blood glucose levels and fetal weight and fetal adipose tissue in diabetic pregnant women. ${ }^{[6-8]}$ Although there is very good glycemic control in diabetic pregnant women, there is still risk for macrosomia. Fetal growth is also affected by factors such as maternal lipids as in addition to glucose. In some studies, a relationship between blood glucose level and maternal triglyceride levels in non-diabetic pregnant women is reported. ${ }^{[9-12]}$ There is a close relationship between maternal nutrition and fetal growth and development. It is reported that fetuses which are older according to their gestational ages are under risk in terms of some diseases both during birth and their postnatal life.

In this study, we investigated the impacts of maternal lipid levels of non-diabetic pregnant women, measured between 25 and 35 weeks of gestation, on fetal weight and neonatal outcomes.

\section{Methods}

The study was conducted on 120 non-diabetic patients at Clinics of Obstetrics and Gynecology, Tepecik Training and Research Hospital. The approval was obtained from the ethics committee of the hospital for the study which was performed prospectively. The exclusion criteria of the study were the diabetes in the medical history, positive screening for gestational diabetes in previous pregnancy, hypertension and lipid metabolism disease, thyroid disease and rheumatic associated disease history which may cause intrauterine growth retardation, and the patients who did not have such conditions were included to the study. For gestational diabetes, $50 \mathrm{~g}$ glucose screening was carried out between 24 and 28 weeks of gestation; those below 135 $\mathrm{mg} / \mathrm{dL}$ were considered as negative for this screening. ${ }^{[13]}$ Fasting maternal lipid levels, total cholesterol (TC), triglyceride (TG), high density lipoprotein (HDL) and low density lipoprotein (LDL) of the patients at between 25 and 35 weeks of gestation were recorded. Also, by measuring heights and weights, body mass index (BMI) was calculated. Routine gestational follow-ups of patients were carried out. The gestational ages of the patients were confirmed by the dates of their last menstrual periods and the ultrasonography of first three months. Delivery weeks, delivery types, fetal gender, fetal weights and newborn data of all patients were recorded.

In the study performed by Kitajima et al., hyperlipidemia was defined as the values above $75 \%$ of each lipid concentration and the values above $259 \mathrm{mg} / \mathrm{dL}$ for triglyceride. ${ }^{[14]}$ In our study, we separated patients into two groups according to their TG values. Those with triglyceride values below $250 \mathrm{mg} / \mathrm{dL}$ were in Group I ( $\mathrm{n}=64)$ and those with triglyceride values above $250 \mathrm{mg} / \mathrm{dL}$ were in Group II $(\mathrm{n}=56)$. These two groups were compared in terms of age, fetal birth weight, glucose screening and delivery weeks.

The patients were also separated into two groups in terms of BMI values as being below and above 25 $\mathrm{kg} / \mathrm{m}^{2}$. Accordingly, those with BMI value below 25 were included into the Group A $(\mathrm{n}=29)$ and those above 25 were included into the Group B ( $n=91)$. Both groups were compared in terms of lipid parameters, birth weights, and glucose screening values.

The data obtained was analyzed by SPSS 16.0 (SPSS Inc., Chicago, IL, USA). Group comparisons were done by student $\mathrm{t}$ test and chi-square test. $\mathrm{p}<0.05$ was considered statistically significant.

\section{Results}

Mean age of the patients was $27.65 \pm 5.40$. Mean delivery week was $38.53 \pm 2.11$, and mean birth weight was $3295.75 \pm 564.58 \mathrm{~g}$. While mean lipid screening week was $32.18 \pm 3.03$, mean lipid values for TC, TG, HDL and LDL were $243.01 \pm 44.24,255.28 \pm 90.27,68.44 \pm 18.52$ and $123,21 \pm 37.11 \mathrm{mg} / \mathrm{dL}$, respectively. Mean BMI value of the patients calculated during the examination was 
Table 1. Demographic and laboratory parameters of the patients.

\begin{tabular}{lcc} 
& Mean \pm SD & Min.-Max. \\
\hline Age (year) & $27.65 \pm 5.40$ & $17-42$ \\
Examination week & $32.18 \pm 3.03$ & $25-35$ \\
TC (mg/dL) & $243.01 \pm 44.24$ & $160-393$ \\
TG (mg/dL) & $255.28 \pm 90.27$ & $82-753$ \\
HDL (mg/dL) & $68.44 \pm 18.52$ & $32-146$ \\
LDL (mg/dL) & $123.21 \pm 37.11$ & $30-274$ \\
Fetal weight (g) & $3295.75 \pm 564.58$ & $550-4620$ \\
Glucose screening (mg/dL) & $99.32 \pm 19.49$ & $60-137$ \\
Delivery week & $38.53 \pm 2.11$ & $24-41$ \\
Body mass index & $28.29 \pm 4.24$ & $20.8-42.1$ \\
\hline
\end{tabular}

$28.29 \pm 4.24 \mathrm{~kg} / \mathrm{m}^{2}$ and mean value of $50 \mathrm{~g}$ glucose screening was $99.32 \pm 19.49 \mathrm{~g} / \mathrm{dL}$ (Table 1). In terms of fetal gender, $65(54.16 \%)$ of fetuses were female, and 55 $(45.83 \%)$ of them were male. For delivery types, $55 \%$ $(66 / 120)$ of the patients had normal delivery while $45 \%$ (54/120) of them had cesarean delivery. Hypospadias anomaly was detected in two cases. Eight cases required respiration support due to the diagnosis of respiratory distress syndrome. Babies born at or above $4000 \mathrm{~g}$ were considered as macrosomic, and macrosomic baby rate was found as $10.83 \%(13 / 120){ }^{[15]}$

When Group I and Group II were compared in terms of age, fetal birth weight, glucose screening and birth weeks, statistically no significant difference was detected between two groups (Table 2). Also, no correlation was found between TG levels and fetal weight ( $\mathrm{p}=0.881, \mathrm{r}=-0.014)$.

There was statistically significant difference between Groups A and B in terms of HDL values $(p=0.02)$. Accordingly, HDL values were lower in the group with higher BMI values. TG values were also higher in the

Table 2. Comparison of the groups according to triglyceride levels (Group I: TG<250, Group II: TG $\geq 250$ ).

\begin{tabular}{lccc} 
& \multicolumn{2}{c}{ Mean \pm SD } & p value \\
\cline { 2 - 3 } & $\begin{array}{l}\text { Group I } \\
(\mathbf{n}=64)\end{array}$ & $\begin{array}{c}\text { Group II } \\
(\mathbf{n}=56)\end{array}$ & \\
\hline Age & $27.8 \pm 5.3$ & $27.5 \pm 5.4$ & 0.777 \\
Fetal weight (g) & $3343.5 \pm 451.1$ & $3241.0 \pm 671.4$ & 0.323 \\
Glucose screening $(\mathrm{mg} / \mathrm{dL})$ & $100.1 \pm 19.2$ & $98.3 \pm 19.8$ & 0.626 \\
Delivery week & $38.4 \pm 1.6$ & $38.6 \pm 2.5$ & 0.538 \\
\hline
\end{tabular}

group with higher $\mathrm{BMI}$ values $(\mathrm{p}=0.031)$. No difference was found when both groups were compared in terms of TC, LDL, fetal birth weight, glucose screening and delivery week (Table 3).

\section{Discussion}

It has been reported that there is an increase in obesity prevalence during pregnancy in recent years. ${ }^{[15]}$ Fetal birth weight is affected by various factors such as pregestational BMI value of mother, weight gained during pregnancy, pregnancy duration and male fetal gender. Change in fetal weight is closely associated with the amount of neonatal adipose tissue. Fetal growth retardations are also probably affected by the changes in maternal and fetal lipid metabolism. According to our study, no relationship was detected between maternal fasting lipid levels and fetal changes. The patients were grouped according to BMI category and compared. Patients with normal and low weights were in a group while overweight and obese patients were in the other group. When both groups were compared, HDL values were found to be lower in the group with higher BMI values $(p=0.02)$. It is an expected result that cardioprotective HDL values decrease as weight increases. Also, TG values were found to be higher in the group with high BMI values $(p=0.031)$. Maternal hypertriglyceridemia is an expected result usually at the last trimester of pregnancy. ${ }^{[4]}$ Triglyceride cannot reach fetus by passing beyond the placenta directly. Lipoprotein receptors in the placenta, proteins binding free fat acid and lipase activities and maternal free fat acids passes to fetus..$^{[3,16,17]}$

Maternal weight has a critical role for determining fetal weight. Even though the reason is unclear, it is thought that genetic factors shared between mother and

Table 3. Comparison of the groups according to body mass index.

\begin{tabular}{|c|c|c|c|}
\hline & \multicolumn{2}{|c|}{ Mean士SD } & \multirow[t]{2}{*}{ p value } \\
\hline & $\begin{array}{c}\text { Group A } \\
(n=29)\end{array}$ & $\begin{array}{c}\text { Group B } \\
(n=91)\end{array}$ & \\
\hline $\mathrm{TC}(\mathrm{mg} / \mathrm{dL})$ & $247.32 \pm 36.91$ & $241.64 \pm 46.44$ & 0.556 \\
\hline $\mathrm{TG}(\mathrm{mg} / \mathrm{dL})$ & $223.36 \pm 88.63$ & $265.44 \pm 88.8$ & 0.031 \\
\hline $\mathrm{HDL}(\mathrm{mg} / \mathrm{dL})$ & $77.54 \pm 23.63$ & $65.55 \pm 15.65$ & 0.020 \\
\hline $\mathrm{LDL}(\mathrm{mg} / \mathrm{dL})$ & $124.86 \pm 23.85$ & $122.68 \pm 39.51$ & 0.788 \\
\hline Fetal weight (g) & $3163.10 \pm 505.89$ & $3338.02 \pm 578.24$ & 0.147 \\
\hline Glucose screening (mg/dL) & $97.03 \pm 17.26$ & $100.05 \pm 20.18$ & 0.470 \\
\hline Delivery week & $38.07 \pm 1.73$ & $38.68 \pm 2.20$ & 0.175 \\
\hline
\end{tabular}


fetus are effective. Just glucose control is not sufficient to stop fetal growth ongoing especially in obese women. It was shown by Langer et al. that initiating insulin treatment as well prevents fetal macrosomia due to antilipolytic effect of insulin. ${ }^{[18]}$ Therefore, decrease in maternal free fat acids and TG levels causes fetal adipose tissues to reduce. According to the study of Knop and Kitajima, TG levels are effective in determining macrosomia free of BMI. ${ }^{[11,14]}$ In our study, although it is found that TG levels are higher in the group with high BMI, no difference was found among fetal weights. In the study performed by Kitajima et al., they found that maternal fasting TG levels in non-diabetic patients who were positive for glucose screening between 24 and 32 weeks of gestation but negative for oral glucose tolerance test were correlated with fetal birth weight at term independent from glucose and obesity, and therefore maternal TG levels measured in mid-gestational period are the independent indicators for detecting macrosomia. In the study carried out by Son et al., it was emphasized that maternal fasting TG levels in patients with gestational diabetes can determine the possibility to deliver large baby independent from weight gained during pregnancy, BMI, age and parity. ${ }^{[19]}$ In our study, no difference was found between fasting maternal TG levels between 25 and 35 weeks of gestation and fetal birth weight, delivery week and glucose screening values. This result makes us to think that other factors in addition to maternal glucose and lipid parameters may also be effective on determining fetal birth weight. Since lipid levels are not checked in fetal cord blood, it is not possible to interpret the relationship with maternal lipid levels. In the studies performed, it has been found that there is correlation between lipid levels in fetal cord blood and maternal lipid levels. Lipoprotein lipase (LPL) is significant in lipid metabolism. It is found in capillary endothelium of extra hepatic tissues, and they have a role in hydrolysis of triglyceride-rich lipids (VLDL and chylomicron) into free fat acid and glycerol. It is though that lipoprotein lipase is effective on the development of fetal adipose tissue and fetal weight. In fetuses with low weight according to their week of gestation, triglyceride levels are high associated with low levels of LPL. Insufficient use of triglyceride in peripheral tissue also causes decrease in fetal adipose tissue and low birth weight. Placental LPL is significant for passing maternal lipids to the fetus in terms of creating fetal adipose tissue substrate.

According to the study of Hyperglycaemia and Adverse Pregnancy Outcome (HAPO), there is a close relationship between BMI and poor obstetric outcomes. Additionally, the risk for delivering macrosomic fetus increases in patients who have high BMI before pregnancy. ${ }^{[10]}$ Birth traumas, shoulder dystocia and cesarean delivery rates increase in macrosomic fetuses. Also, it has been found that nutritional environment that such babies are exposed in intrauterine life also has a determining role for the postnatal life. It is reported that they are under risk especially in terms of obesity, cardiovascular diseases and type-II diabetes. In the determination of fetal macrosomia, studies on enzymes and hormones creating and arranging fetal adipose tissue as well as maternal glucose and lipid parameters are also required.

\section{Conclusion}

As a conclusion, no relationship was found in our study between fetal birth weights and maternal lipid levels of non-diabetic pregnant women. TG levels were found to be higher in those who have high BMI values, and HDL values were found to be lower.

Conflicts of Interest: No conflicts declared.

\section{References}

1. Kostner GM. Correlation of hormones with lipid and lipoprotein levels during normal pregnancy and postpartum. J Clin Endocrinol Metab 1987;64:704-12.

2. Sattar N, Greer IA, Louden J, Lindsay G, McConnell M, Shepherd J, et al. Lipoprotein subfraction changes in normal pregnancy: threshold effect of plasma triglycerides on appearance of small, dense, low density lipoprotein. J Clin Endocrinol Metab 1997;82:2483-91.

3. Herrera E, Munilla MA. Maternal lipid metabolism and its implications for fetal growth. In: Battaglia FC, editor. Placental function and fetal nutrition. Nestle' Nutrition Workshop Series, Vol. 39. Philadelphia: Lippincott-Raven; 1997; p: 16982.

4. Montelongo A, Lasunción M, Pallardo L, Herrera E. Longitudinal study of plasma lipoproteins and hormones during pregnancy in normal and diabetic women. Diabetes 1992;1651-9.

5. Pedersen J. Weight and length at birth of infants of diabetic mothers. Acta Endocrinol 1954;16:330-42.

6. Durnwald C, Huston PL, Amini S, Catalano P. Evaluation of body composition of large-for-gestational-age infants of women with gestational diabetes mellitus compared with women with normal glucose tolerance levels. Am J Obstet Gynecol 2004;191:804-8.

7. Catalano PM, Thomas A, Huston PL, Amini SB. Increased fetal adiposity: a very sensitive marker of abnormal in utero development. Am J Obstet Gynecol 2003;189:1698-704. 
8. Son GH, Kwon JY, Kim YH, Park YW. Maternal serum triglycerides as predictive factors for large-for-gestational age newborns in women with gestational diabetes mellitus. Acta Obstet Gynecol Scand 2010;89:700-4.

9. Sermer M, Naylor CD, Gare DJ, Kenshole AB, Ritchie JW, Farine D, et al. Impact of increasing carbohydrate intolerance on maternal-fetal outcomes in 3637 women without gestational diabetes. The Toronto Tri-Hospital Gestational Diabetes Project. Am J Obstet Gynecol 1995;173:146-56.

10. Metzger BE, Lowe LP, Dyer AR, Trimble ER, Chaovarindr U, Coustan DR, et al.; HAPO Study Cooperative Research Group. Hyperglycemia and adverse pregnancy outcomes. N Engl J Med 2008;358:1991-2002.

11. Knopp RH, Magee MS, Walden CE, Bonet B, Benedetti TJ. Prediction of infant birth weight by GDM screening tests. Importance of plasma triglyceride. Diabetes Care 1992;15: 1605-13.

12. Di Cianni G, Miccoli R, Volpe L, Lencioni C, Ghio A, Giovannitti MG, et al. Maternal triglyceride levels and newborn weight in pregnant women with normal glucose tolerance. Diabet Med 2005;22:21-5.

13. Carpenter M, Coustan DR. Criteria for screening tests for gestational diabetes. Am J Obstet Gynecol 1982;144:768-73.
14. Kitajima M, Oka S, Yasuhi I, Fukuda M, Rii Y, Ishimaru T. Maternal serum triglyceride at 24-32 weeks' gestation and newborn weight in nondiabetic women with positive diabetic screens. Obstet Gynecol 2001;97:776-80.

15. Retnakaran R, Ye C, Hanley AJ, Connelly PW, Sermer M, Zinman B, et al. Effect of maternal weight, adipokines, glucose intolerance and lipids on infant birth weight among women without gestational diabetes mellitus. CMAJ 2012; 184:1353-60.

16. Cummings S, Hatley W, Simpson E: The binding of high and low density lipoproteins to human placental membrane fractions. J Clin Endocrinol Metab 1982;54:903-8,

17. Bonet B, Brunzell J, Gown A, Knopp R. Metabolism of verylow-density lipoprotein triglyceride by human placental: the role of lipoprotein lipase. Metabolism 1992;41:596-603.

18. Langer O, Yogev Y, Xenakis E, Brustman L. Overweight and obese in gestational diabetes: the impact on pregnancy outcome. Am J Obstet Gynecol 2005;192:1768-76.

19. Son GH, Kwon JY, Kim YH, Park YW. Maternal serum triglycerides as predictive factors for large-for-gestational age newborns in women with gestational diabetes mellitus. Acta Obstet Gynecol Scand 2010;89:700-4. 